\title{
Testing the Effectiveness of Altman and Beneish Models in Detecting Financial Fraud and Financial Manipulation: Case Study Kuwaiti Stock Market
}

\author{
Raif M. Akra ${ }^{1} \&$ Jamil K. Chaya ${ }^{1}$ \\ ${ }^{1}$ College of Business Administration, Rafik Hariri University, Lebanon \\ Correspondence concerning this article should be made to Dr. Jamil Chaya at Rafik Hariri University, College of \\ Business Administration, Mechref city, Chouf, Lebanon. E-mail: chayajk@rhu.edu.lb
}

Received: June 28, 2020

Accepted: August 20, 2020

Online Published: September 16, 2020

doi:10.5539/ijbm.v15n10p70

URL: https://doi.org/10.5539/ijbm.v15n10p70

\begin{abstract}
This study is an adoption of two probabilistic financial analysis methods, Altman and Beneish Models that have proven effective in early detection of possible financial distress and profit manipulation respectively. Motivated by the effectiveness of the models, this paper applies the methodology on the Kuwaiti Stock Market excluding banking and insurance companies. Results demonstrated that Altman has less predictive power in the context of industrial and real estate companies while Beneish has a strong predictive power to uncover possible manipulation in earnings or fraudulent reporting in the tested companies as confirmed with an ex-post review of the companies and news sources. We recommend a recalibration of the Altman model according to industry in addition to recommending that financial analysts and interested parties use both models.
\end{abstract}

Keywords: Altman, Z-Score, Beneish, m-score, financial fraud, financial manipulation

\section{Introduction}

Corporate fraud has been a great fear for organizations and investors and threatens public trust and confidence. In a definition of fraud, (KPMG, 2015) stated that it is a global act that is done on purpose where the perpetrator commits an illegal or unlawful act for a certain personal gain or personal advantage. It is implemented through deceiving others and causing significant losses for victims such as investors, banks, owners, and other stakeholders. The most common type of fraud is to manipulate financial statements where it turns to be unreflective of the true performance of the company and causes shaking inconsistency for users of these financial statements. It is the fact that fraud is considered a serious issue as the consequences would be either in the collapse of the company and defrauding of investors. Big four companies such as (Deloitte, 2008) found that bankruptcy and fraud are endogenous variables where they both affect each other and both are related to each other. For instance, a company who is on the verge of its bankruptcy is more likely to commit fraud in an act of last resort. Management is more likely to commit fraud in these cases in order to paint a better picture of the company to its shareholders.

On the other hand, bankruptcy can be a result of the ongoing commitment of fraud by the company's management (Association of Certified Fraud Examiners, 2008). Therefore, distressed management are the major reason behind a fraudulent company which flags the need to implement models such as Beneish M-score and Altman Z-score model on the financial statements as detectors of the company's possibility of having distressed management and whether the financial statements were manipulated or not (MacCarthy, 2017). However, this researcher suggests the need to employ Beneish M-score before employing Altman Z-score as the former informs us whether the company has done any manipulation to the financial statements while the latter informs us whether the company's management was distressed and committed the fraud prior the collapse or not.

As fraud and bankruptcy increased significantly in global companies which urged researchers and academics to question the accuracy and effectiveness of financial models in fraud detection and financial statements manipulation. They suggested that such models were not popular at Enron's collapse periods and users of the financial statements relied on the work of external auditors rather than the work of paid financial analysts. 


\section{Theoretical Framework}

\subsection{The Altman Model}

The Altman Z-score Model contributed to the literature extensively and provided a solid background for theorists in constructing models to predict manipulations of financial statements or possible corporate failure. The seminal work of Edward Altman (Altman, Financial ratios, discriminant analysis and the prediction of corporate bankruptcy., 1968) used a quantitative model to analyze the firms' potential of a corporate failure. He initially listed 22 financial variables for evaluation and then narrowed them down to 5 robust survivors and placed these variables into 5 categories: liquidity, solvency, leverage, profitability, and activity ratios. The chosen variables were selected based on their effectiveness to reflect corporate bankruptcy based on the lead time of 7 months and a half that proved to be the time before a bankruptcy occurs. Research (Robinson \& Magure, 2001) does underscore that Altman Z-score is a type of quantitative model, also known as Multiple Discriminant Analysis (MDA), that assesses the likelihood (not probability) of a company being in a distress. The model is capable to distinguish between companies that are distressed and those that are not. In a description of this formula, this 5component equation represent five figures from the financial statements that allows the analyst to gauge the possibility of distress in the following two years. Equation 1 displays the results of Altman's work where we note that the coefficients of the equation are derived from econometric analysis.

$$
\text { Zscore }=1.2 X_{-} 1+1.4 X_{-} 2+3.3 X_{-} \_3+0.4 X_{-} 4+1 X_{-} 5
$$

The ratios of the dependent variables are described by Altman in the following manner (Altman, 1968).

\subsection{1 $\mathrm{X}_{1}=$ Net Working Capital / Total Assets}

This variable portrays the activity of the firm under assessment, and the type of company plays a major role in the outcomes. For instance, in a manufacturing company, the size \& timing of the inventory along with that of the accounts receivable plays a big role in impacting safety and ratio analysis. If the company is facing any issues with its liquidity and in its working capital in specific (current assets - current liabilities), then this would provide a valuable input to the effectiveness of the Altman's test. Moreover, this ratio was modified to represent each type of firm properly. For example, in manufacturing, working capital represents inventory and its potential cash liquidity of inventory, but in banking industry, working capital is composed of demand deposits and short term loans as banks do not hold inventory.

\subsection{2 $\mathrm{X}_{2}=$ Retained Earnings / Total assets}

This represents the surplus of earnings in a company and does not differ significantly in different industries.

\subsection{3 $\mathrm{X}_{3}=$ Earnings before Income Tax (EBIT) / Total Assets}

The major reason behind including this variable is in the power of earnings for the success of any firm and its use in communicating profitability for analysts. The earning power of assets was used by (Altman \& Lavalle, 1981) as a key estimator of possible failure.

\subsection{4 $\mathrm{X}_{4}=$ Market Value of Equity / Book Value of Total Debts}

In his model, (Altman, Financial ratios, discriminant analysis and the prediction of corporate bankruptcy., 1968) used this ratio to include major components of the financial statements which are equity and total liabilities. Equity is important to be included as it represents different equity instruments such as common stock, preferred, and all types. However, this ratio proved to be effective for public and listed corporations and least effective for private companies as reliable estimates for market value are not available.

\subsection{5 $\mathrm{X}_{5}=$ Sales / Total Assets}

This ratio which is also known to capital turnover proved to be highly capable and effective as a discriminant variable. This is to reflect the sales generating capability, it was excluded by Altman in future models as it varies among different industries.

The dependent variables scaled by the original coefficients serve to derive the Z-score. Scores are benchmarked against threshold values established in Altman's seminal work where the value could fall under non-distress (above 2.67), "grey zone" (between 1.81 and 2.67), or distress (below 1.81).

\subsection{The Beneish Model}

A secondary model emerged complimenting Altman's (Beneish, 1999) with an emphasis to protect a company's external stakeholders such as creditors and investors is the Beneish Model based an M-Score. This forensic model aims to quantify and identify probable financial statement manipulators. This is a probability model that predicts manipulation almost $76 \%$ of the time for further investigation rather than assures a $100 \%$ manipulation. It uses 
eight variables from the financial statements to derive an M-score which in turn is used to identify likely offenders. The threshold of this model is -2.22 where anything higher suggests possible manipulation. Below is a description of the eight variables used in the Beneish Model as cited by MacCarthy (2017).

\subsubsection{Day Sales in Receivables Index (DSRI)}

$$
\text { DSRI }_{t}=\frac{\text { Account.Receivable }_{t}}{\text { Sales }_{t}} / \frac{\text { Account Receivable }_{t-1}}{\text { Sales }_{t-1}}
$$

This ratio is indicative of the consistency in the change between sales and accounts receivables. The financial statements prove to be non-manipulated if the score of this ratio is 1.031 or less, but if it is 1.465 and more than this indicates that the financial statements may be manipulated and that the company is granting more credit than before. This also means that either the company is doing more credit sales or it is unable to collect its credit sales. Therefore, a high score suggests overstated revenues or manipulation in terms of credit sales.

\subsubsection{Gross Margin Index (GMI)}

$$
\text { GMI }_{t}=\frac{\text { Sales }_{t-1}-\text { COGS }_{t-1}}{\text { Sales }_{t-1}} / \frac{\text { Sales }_{t}-\text { CoG }_{t}}{\text { Sales }_{t}}
$$

According to Harrington (2005), a score of 1.041 or less indicates that gross profit is not likely manipulated, but a ratio of 1.193 or more suggests possible manipulation.

\subsubsection{Assets Quality Index (AQI)}

$$
A Q I_{t}=\left[1-\frac{\text { Current. }_{\text {Asset }}+P \text { PPE }_{t}+\text { Securities }_{t}}{\text { Total.Assets }_{t}}\right] /\left[1-\frac{\text { Current.Asset }_{t-1}+P \text { PEE }_{t-1}+\text { Securities }_{t-1}}{\text { Total.Assets }_{t-1}}\right]
$$

This ratio takes the changes in total assets type from one year to the second (between the current and previous). An increase in this ratio ( 1 or more) means that some intangible assets or expenses are capitalized (Pustylnick, 2009). Researchers such as Harrington (2005) mentioned that an increase would also indicate that more expenses are capitalized rather than written off in order to preserve profits.

\subsubsection{Sales Growth Index (SGI)}

$$
\operatorname{SGI}_{t}=\text { Sales }_{t} / \text { Sales }_{t-1}
$$

This ratio should be less than 1.134 to suggest non-manipulation in sales figures, and a score above 1.607 to suggest manipulation. Companies who had high growth rates tend to manipulate if any reverse trend occurs.

\subsubsection{Depreciation Index (DEPI)}

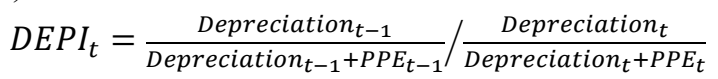

This ratio measures the amount of depreciation expense against its Property, Plant, Equipment. A ratio of 1.001 or below indicates that DEPI suggests unlikely manipulation, while a score above 1.077 suggests that assets may have been revalued or adjusted upward such as increasing useful life of years as a way to manipulate (Beneish, 1999).

\subsubsection{Sales, General \& Administrative Index (SGAI)}

$$
S G A I_{t}=\frac{S G \& A_{t}}{\text { Salest }} / \frac{S G \& A_{t-1}}{\text { Sales }_{t-1}}
$$

This ratio is used to measure the current year values of SGAI against the previous year. A score of less than 1.001 suggests non-manipulation while a score with a positive relation hints at a likely manipulation.

\subsubsection{Leverage Index (LI)}

$$
\text { LI }_{t}=\frac{\text { Curr.Liabilities }_{t}+\text { Long.Term.Debt }_{t}}{\text { Total.Assets }_{t}} / \frac{\text { Curr.Liabilities }_{t-1}+\text { Long.Term.Deb }_{t-1}}{\text { Total.Assets }_{t-1}}
$$

This ratio is used to measure debt over assets of the current year over the previous ones. A ratio of 1 or more means that the company is taking on more credit to continue operating.

\subsubsection{Total Accruals to Total Assets Index (TATAI)}

$$
\text { TATAI }=\left(\text { Income. Continuing. } \text { Operations }_{t}-\text { CFO }_{t}\right) / \text { Total. Assets } t
$$

This ratio is used to measure the change in working capital which is non-cash less depreciation. A growth in this ratio means that there is a possible manipulation in amortization and goodwill numbers (accruals). A score of 0.018 suggests non-manipulation while a score of 0.031 and above hints at financial manipulation.

Based on these weights, the formula of M-score is displayed in equation 2 


$$
\begin{gathered}
\text { M. Score }=-4.84+0.92 * D S R I+0.528 * G M I+0.404 * A Q I+0.892 * S G I+0.115 * D E P I \\
-0.172 * S G A I+4.679 * T A T A I-0.327 * L I
\end{gathered}
$$

Where the M-Score intervals range from: below -2.22 "unlikely profit manipulation", between -2.22 and -1.78 "possible profit manipulation", and above -1.78 "likely profit manipulation".

\section{Literature Review}

According to MacCarthy (2017), Enron Corporation violated GAAP standards in three ways which are manipulating the derivatives, role of mark-to-market rules, and off-balance sheet arrangements. The major issue is that Enron's management reported $390 \%$ growth based on projected power prices in the future. They failed to follow the special purpose entity and they through relocated their debt off the partnership books. The financial statements showed fictitious gains from derivatives and sudden increases from derivatives from $\$ 1.9$ billion to reach $\$ 10.5$ billion in 2000. McCarthy (2017) used a quantitative research methodology to discover the true position of Enron prior the crisis. Referring to Altman and Beneish models. The main hypotheses of that study was that Enron displayed signs of financial failure prior to its occurrence and that financial statements were manipulated prior the crisis. The researchers were able to utilize Multiple Discriminant Analysis that was formulated from these tests. The results of Z-score and M-score accepted these null hypotheses. Enron proved to be in the distressed zone but they were not distressed. The results of Beneish Model showed that variables were manipulated prior the collapse, and the results of Altman failed to prove that the company was in a true distress. Therefore, these results proved that the company manipulated its financial statements in order to conceal its true financial position but Altman model was not strong enough to prove distress of Enron prior the corporate failure. However, the author mentioned that manipulation occurred as a consequence of major issues. Therefore, if the company and investors utilized the Beneish Model prior to the collapse, they would have at least been able to flag certain issues. Notably, undergraduate students from Cornell University utilizing the Beneish M-Score effectively recognized Enron as a manipulator of profits when experienced financial analysts failed to do so (Newstex Global Business, 2016).

Alareeni and Branson (2013) applied these models in Jordan as a developing country. They have selected 71 failing companies and compared the model results with 71 non-failing companies that are in the same industry (manufacturing and service) and of comparable size in terms of asset. The major aim of this study was to measure the relevance of these models in the Jordanian context. They retrieved data for three years prior to a failure from the records of bankrupt companies in the Ministry of Industry \& Trade database. Moreover, they retrieved data of companies who witnessed losses in the past three years from the Companies Control Department at the Ministry of Industry and Trade. They excluded banks and insurance companies as the predictors of failure in these institutions vary significantly from other service companies. Results of this study proved the following:

The predictive power of Altman model in industrial companies is high in evaluating the possible failure in these types of companies in the Jordanian context.

The predictive power of Altman Model in service companies is low in its capability to detect possible failure in the Jordanian context.

The Beneish model was able to distinguish roughly $50 \%$ of the organizations that engaged with profit manipulation before they were found. The model also effectively recognized early 12 of the 17 most prominent manipulation cases in the period 1998 to 2002. The M-Score identified these companies that improved their stocks' returns in the period between 1993 to 2007 as a result of potential manipulation. During the 15-year time span, stocks that were distinguished as potential profit controllers by the M-Score returned $9.7 \%$ not as much as stocks that were not recognized.

In Malaysia, researchers investigated the effectiveness of these models in predicting fraudulent reporting (Roshayani, Sharinah, \& Normah, 2015). Fraudulent reporting practices would result in serious losses for investors. Enron is the best example how investors were victimized by a fierce drop share prices due to the announcement of the company's fraudulent acts. The importance of early detection could not be overstated. In this study, researchers selected 24 failing firms that are listed on Bursa Malaysia and they compared it with 24 non-failing firms. They retrieved the financial statements of these companies over the period of 2004-2012 which is the period of five years prior the failure and after its occurrence. The selection process ensured that control groups of nonfailing firms and failing firms should share the following criteria:

- Stock exchange: this requires that both types of companies have the same stock exchange and are both listed. 
- Size of the firm: for each failing company that is selected, there should be a corresponding non-failing company of the same size of assets. In specific, the firms closest asset size should be taken based + or $-30 \%$ of the current assets on the balance sheet of the failing firms.

- Industry: the type of industry is important as the chosen companies should be either industrial, trading \& services, consumer products, real estate, plantation, and these companies excluded financial companies from the sample because of the significant difference in the data.

- Time period: The same time period should be identified for data retrieved from failing and non-failing companies. The time period should be five years prior the announcement of any financial failure.

The researchers used Z-score of Altman model and M-score of Beneish model. The interpretation of data was based on the following criteria:

$\mathrm{Z}$-score should indicate possible bankruptcy within two years considering the zones of discriminations $(\mathrm{Z}>2.99$ means a safe zone, $1.8<\mathrm{Z}<2.99$ means a gray zone, $\mathrm{Z}<1.80$ means a distress zone)

$\mathrm{M}$-score that is less than (-2.2) indicates that the company is not a manipulator; however, a result that is above this score is a negative indicator of a manipulation.

Results of this test showed that $66.7 \%$ of non-failed companies showed that financial statements have been subject to manipulation ( 16 companies out of the 24), and $96 \%$ of 24 failing companies were accurately detected through Altman Z-score. The major limitation in this study is that these models would not be applicable on small sized companies (Roshayani, Sharinah, \& Normah, 2015).

Small and medium enterprises are among the riskiest enterprises to be subject to fraud as results proved that these enterprises reported higher fraudulent activities than large enterprises (Aris, Arif, \& Zain, 2015). They chose a certain automotive company in Malaysia to test it for fraud detection. To do this objective, they utilized two tests which are Altman Z-score and Beneish M-score. These were referred to as statistical fraud detection methods that are necessary to improve the operations of the company. They data mined the financial records of the company and retrieved data for the period of 2010 to 2012. The input variables that were used in this study were: net sales, SGA expense, net profit, current assets, net receivables, cost of goods sold, plant property and equipment (PPE), total assets, net profit, and cash flow from operating activities, current liabilities, and long term debt. These input variables were included to construct each model of the three methods. For example, eight of these variables were included in the Beneish model. Results proved that there were major threats of manipulation in Gross Margin Index (GMI) and Days' Sales in Receivables Index (DSRI). The threat was noticed from the logic that the company showed low Sales Growth Index (SGI) with a higher GMI. This contradicts the truth that a higher GMI is usually triggered by higher sales, which means it should be associated with a higher SGI. On the other hand, the results of Altman Z-score showed that the company is in healthy position where it scored 3 for two years and signaled growth in the results of its equity over liabilities. These researchers recommended the company to enhance its internal audit work to include application of occasional statistical models' fraud detection. These methods proved to be effective in protecting the company from the debilitating fraud effects.

Early fraud detection through traditional financial analysis is certainly time-consuming. The effectiveness of the M-score (Beneish) and Z-score (Altman) is significant as has been shown in the literature. The Beneish model can confound exceptional performance for manipulations (Type I errors). The consolidated utilization of both models in the developing markets will is recommended.

Bhavani and Tabi (2017) called these tests forensic tools of fraud detection. They compared both models to test their effectiveness in the context of Toshiba's financial statements for the time span of 2008-2014. The results of this research concluded that the Beneish Model lacked effectiveness as it failed to indicate that the company's financial statements were flawed. However, the Altman model was more effective in its capability to detect fraud at an early stage. This was against what was hypothesized for the Beneish Model as it is known for its efficacy in this context. The results of this research were provided as an effective reference for the users of the Toshiba's financial statements such as investors, financial, and forensic auditors as well. The general M-score was found to be 2.22 which indicate that Toshiba was not manipulating its earnings during this period which was then opposed by the Japanese government. The eight variables model of Beneish failed to spot the occurring manipulation and was not capable in identifying the occurring material misstatements. On the other hand, Altman Z-score which is used to detect bankruptcy at an early stage was effective to notice that Toshiba would not last in the market so long. It succeeded to foresee that the company is in danger to file bankruptcy within two years. This was because the low working capital the company had and the liquidity problems that it signaled. Liquidity reflected the possibility of the company's insolvency in the near future. Moreover, the ratio of earnings to total assets was low which reflected the low profitability of the company. These results mean that the company would be using its profits to 
cover losses and liquidity issues. Moreover, the two measurable models utilized in the investigation were valuable for showing warnings in regards to the extent of the manipulation at Toshiba, but neither model could pinpoint the specific area or region of the misrepresentation or fraud.

In Poland, using Beneish score was effective in the detection fraud in earning management practices in Polish companies (Golec, 2019). This study covered 24 Polish companies. Results demonstrated that at the -2.22 cut-off point, the model was effective to distinguish $67 \%$ of manipulators and $75 \%$ of non-manipulators. As the cut-off point became -1.98, the precision of Beneish model improved from $71 \%$ to $75 \%$. Another perception was that high changes in M-Score values ended up being better pointer of control and the grouping dependent on $35 \%$ change in year-to-year values arrived at $85 \%$ exactness.

In a study that was done on Z manufacturing a firm in Zimbabwe, Altman Z score (a predictor of bankruptcy) and Beneish $M$ score (a predictor of earnings manipulation) was utilized on the financial statements of the company for the time period 2011 to 2014 (Mavengere, 2015). Results demonstrated that Altman and Beneish models were effective enough to uncover possible bankruptcy and an occurring earnings manipulation. Results of this study revealed that $Z$ company is in the grey zone using Z-score in 2011 while it moved to the financial distress zone in the period of 2012-2014. Moreover, the results of M-score proved the company to be an earnings manipulator where it showed scores of -2.11 and -0.10 in 2010 and 2014. These results were noticed when they benchmarked against manipulators' mean. For instance, manipulator mean of days receivables was 1.465 , but the company's records showed 1.53 which is superior to this mean. The Gross Margin Index (GMI) showed 1.51 and 4.83 in 2013 and 2014 respectively which is superior to the manipulation mean of 1.193. The Securities Exchange would be aided extensively by these models in order to detect possible fraudulent reporting activities at an early stage. The presence of these models would decrease the investors' fears regarding a possible sudden financial failure in the light of the successive global company failures.

In summary of the above review of literature, we noted first the effectiveness of the two models in their predictive ability in developing economies and a gap in the Kuwait context.

\section{Findings}

\subsection{Altman Model}

Table 1. Altman model results

\begin{tabular}{llllllll}
\hline Company Name & X1 & X2 & X3 & X4 & X5 & Results & Interpretation \\
\hline Yiaco Medical Co & 0.01 & -0.27 & -0.12 & 0.20 & 0.88 & 0.21 & Distress \\
Commercial Facilities Company & 0.95 & 0.34 & 0.02 & 0.64 & 0.06 & 2.00 & Grey \\
Kuwait Telecommunications & 0.05 & 0.42 & 0.11 & 2.23 & 0.75 & 2.68 & Non-Distress \\
Sultan Center Food Products & -0.03 & -0.15 & 0.00 & 0.12 & 0.79 & 0.61 & Distress \\
Soukouk Holding & -0.28 & -0.04 & -0.14 & 0.76 & 0.06 & -0.50 & Distress \\
Kuwait Real Estate Company & 0.11 & 0.14 & 0.03 & 0.66 & 0.07 & 0.78 & Distress \\
Arkan Real Estate & -0.42 & 0.15 & 0.03 & 0.67 & 0.06 & 0.15 & Distress \\
United Real Estate Company & -0.20 & 0.09 & 0.01 & 0.15 & 0.17 & 0.15 & Distress \\
THE NATIONAL REAL ESTATE COMPANY & -0.15 & 0.26 & 0.04 & 0.59 & 0.09 & 0.64 & Distress \\
ALARGAN INTERNATIONAL REAL ESTATE CO. & 0.18 & 0.29 & 0.02 & 0.35 & 0.04 & 0.86 & Distress \\
ABYAAR REAL ESTATE DEVELOPMENT CO. & -0.13 & -0.42 & -0.01 & 0.09 & 0.00 & -0.74 & Distress \\
Kuwait National Cinema & 0.02 & 0.49 & 0.05 & 0.73 & 0.15 & 1.33 & Distress \\
Zain MOBILE TELECOMMUNICATIONS COMPANY & -0.05 & 0.11 & 0.07 & 0.72 & 0.35 & 0.98 & Distress \\
Kuwait Cement Company & 0.05 & 0.44 & 0.03 & 1.45 & 0.32 & 1.66 & Distress \\
The commercial real estate & -0.02 & 0.21 & 0.04 & 0.74 & 0.06 & 0.78 & Distress \\
Future Kind \& Entertainment \& Real Estate & 0.25 & 0.20 & 0.04 & 6.20 & 0.34 & 3.54 & Non-Distress \\
Al Midan Clinic for Oral Health Services & 0.35 & 0.19 & 0.16 & 19.26 & 0.97 & 9.88 & Non-Distress \\
Agility Public Warehousing Company & 0.04 & 0.44 & 0.06 & 1.60 & 0.84 & 2.36 & Grey \\
Ajwan Gulf Real Estate & -0.05 & -0.67 & -0.28 & 1.92 & 0.10 & -1.05 & Distress \\
National Industries Group & 0.00 & 0.09 & 0.06 & 0.39 & 0.10 & 0.59 & Distress \\
Heavy Engineering Industrise \& Ship Building Co. & 0.04 & 0.21 & 0.06 & 0.58 & 1.00 & 1.77 & Distress \\
Kuwait Cable Vision & -0.06 & -1.77 & -0.06 & 1.18 & 0.00 & -2.27 & Distress \\
Specialities Group Holding Co. & 0.48 & 0.04 & 0.04 & 1.45 & 0.62 & 1.97 & Grey \\
Dar Al Thuraya Real Estate & 0.04 & 0.01 & 0.04 & 1.10 & 0.12 & 0.74 & Distress \\
\hline
\end{tabular}




\begin{tabular}{llllllll}
\hline Gulf Cable \& Electrical Industries Company & 0.25 & 0.44 & 0.02 & 4.06 & 0.46 & 3.07 & Non-Distress \\
Shuaiba Industrial Co. & 0.32 & 0.24 & 0.04 & 2.51 & 0.63 & 2.49 & Grey \\
Jazeera Airways & 0.06 & 0.12 & 0.09 & 1.60 & 0.62 & 1.79 & Distress \\
Gulf Cement Company & 0.06 & 0.27 & -0.03 & 0.17 & 0.36 & 0.78 & Distress \\
Aan Digital Services & -0.07 & -1.79 & -0.02 & 1.91 & 2.11 & 0.21 & Distress \\
Hayat Communications Company & 0.43 & 0.04 & 0.02 & 0.29 & 0.89 & 1.65 & Distress \\
\hline
\end{tabular}

\subsection{Beneish Model}

Table 2. Beneish model results

\begin{tabular}{|c|c|c|c|c|c|c|c|c|c|c|c|}
\hline Company & $\mathrm{X} 1$ & $\mathbf{X} 2$ & $\mathbf{X} 2$ & $\mathrm{X} 4$ & $\mathrm{X5}$ & $\mathrm{X6}$ & $\mathbf{X} 7$ & $\mathbf{X 8}$ & Results & Interpretation & \\
\hline Yiaco Medical Co & 0.72 & $\begin{array}{l}0.0 \\
0\end{array}$ & $\begin{array}{l}1.0 \\
0\end{array}$ & 0.70 & 0.00 & $\begin{array}{l}1.0 \\
6\end{array}$ & $\begin{array}{l}0.9 \\
9\end{array}$ & $\begin{array}{l}- \\
0.1 \\
6\end{array}$ & -4.43 & $\begin{array}{l}\text { UnLikely } \\
\text { Manipulation }\end{array}$ & Profit \\
\hline $\begin{array}{l}\text { Commercial Facilities } \\
\text { Company }\end{array}$ & 1.03 & $\begin{array}{l}0.0 \\
4\end{array}$ & $\begin{array}{l}1.0 \\
0\end{array}$ & 1.02 & 1.22 & $\begin{array}{l}0.9 \\
0\end{array}$ & $\begin{array}{l}0.5 \\
1\end{array}$ & $\begin{array}{l}0.9 \\
4\end{array}$ & 1.16 & $\begin{array}{l}\text { Likely } \\
\text { Manipulation }\end{array}$ & Profit \\
\hline Kuwait Telecommunications & 0.98 & $\begin{array}{l}0.0 \\
0\end{array}$ & $\begin{array}{l}0.7 \\
5\end{array}$ & 1.02 & 1.17 & $\begin{array}{l}0.8 \\
2\end{array}$ & $\begin{array}{l}0.4 \\
5\end{array}$ & $\begin{array}{l}- \\
0.11\end{array}$ & -3.96 & $\begin{array}{l}\text { UnLikely } \\
\text { Manipulation }\end{array}$ & Profit \\
\hline Sultan Center Food Products & 0.00 & $\begin{array}{l}0.0 \\
0\end{array}$ & $\begin{array}{l}0.0 \\
0\end{array}$ & 1.01 & 2.25 & $\begin{array}{l}1.0 \\
2\end{array}$ & $\begin{array}{l}0.8 \\
5\end{array}$ & $\begin{array}{l}- \\
0.1 \\
6\end{array}$ & -4.97 & $\begin{array}{l}\text { UnLikely } \\
\text { Manipulation }\end{array}$ & Profit \\
\hline Soukouk Holding & 0.47 & $\begin{array}{l}0.0 \\
2\end{array}$ & $\begin{array}{l}0.8 \\
6\end{array}$ & 0.98 & 0.00 & $\begin{array}{l}1.1 \\
9\end{array}$ & $\begin{array}{l}0.3 \\
6\end{array}$ & $\begin{array}{l}- \\
0.3 \\
1\end{array}$ & -5.75 & $\begin{array}{l}\text { UnLikely } \\
\text { Manipulation }\end{array}$ & Profit \\
\hline $\begin{array}{lll}\text { Kuwait } & \text { Real } & \text { Estate } \\
\text { Company } & & \end{array}$ & 0.95 & $\begin{array}{l}0.0 \\
3\end{array}$ & $\begin{array}{l}1.0 \\
0\end{array}$ & 1.02 & 1.16 & $\begin{array}{l}1.1 \\
5\end{array}$ & $\begin{array}{l}0.5 \\
1\end{array}$ & $\begin{array}{l}0.1 \\
0\end{array}$ & -2.86 & $\begin{array}{l}\text { UnLikely } \\
\text { Manipulation }\end{array}$ & Profit \\
\hline Arkan Real Estate & 1.61 & $\begin{array}{l}0.2 \\
4\end{array}$ & $\begin{array}{l}1.0 \\
0\end{array}$ & 1.13 & 1.41 & $\begin{array}{l}0.9 \\
2\end{array}$ & $\begin{array}{l}0.4 \\
7\end{array}$ & $\begin{array}{l}- \\
0.4 \\
4\end{array}$ & -4.57 & $\begin{array}{l}\text { UnLikely } \\
\text { Manipulation }\end{array}$ & Profit \\
\hline United Real Estate Company & 0.86 & $\begin{array}{l}0.0 \\
0\end{array}$ & $\begin{array}{l}0.9 \\
0\end{array}$ & 1.19 & 1.36 & $\begin{array}{l}0.8 \\
9\end{array}$ & $\begin{array}{l}0.6 \\
9\end{array}$ & $\begin{array}{l}- \\
0.2 \\
2\end{array}$ & -4.11 & $\begin{array}{l}\text { UnLikely } \\
\text { Manipulation }\end{array}$ & Profit \\
\hline $\begin{array}{l}\text { THE NATIONAL REAL } \\
\text { ESTATE COMPANY }\end{array}$ & 3.53 & $\begin{array}{l}0.0 \\
1\end{array}$ & $\begin{array}{l}1.0 \\
0\end{array}$ & 0.77 & 1.04 & $\begin{array}{l}1.4 \\
5\end{array}$ & $\begin{array}{l}0.4 \\
6\end{array}$ & $\begin{array}{l}- \\
0.1 \\
7\end{array}$ & -2.11 & $\begin{array}{l}\text { Possible } \\
\text { Manipulation }\end{array}$ & Profit \\
\hline $\begin{array}{l}\text { ALARGAN } \\
\text { INTERNATIONAL REAL } \\
\text { ESTATE CO. }\end{array}$ & 1.46 & $\begin{array}{l}0.1 \\
5\end{array}$ & $\begin{array}{l}1.0 \\
0\end{array}$ & 0.55 & 1.08 & $\begin{array}{l}1.7 \\
8\end{array}$ & $\begin{array}{l}0.4 \\
7\end{array}$ & $\begin{array}{l}0.1 \\
6\end{array}$ & -2.64 & $\begin{array}{l}\text { UnLikely } \\
\text { Manipulation }\end{array}$ & Profit \\
\hline $\begin{array}{l}\text { ABYAAR REAL ESTATE } \\
\text { DEVELOPMENT CO. }\end{array}$ & 0.00 & $\begin{array}{l}0.0 \\
0\end{array}$ & $\begin{array}{l}1.0 \\
0\end{array}$ & 0.00 & 1.93 & $\begin{array}{l}0.0 \\
0\end{array}$ & $\begin{array}{l}0.6 \\
4\end{array}$ & $\begin{array}{l}- \\
0.1 \\
4\end{array}$ & -5.39 & $\begin{array}{l}\text { UnLikely } \\
\text { Manipulation }\end{array}$ & Profit \\
\hline Kuwait National Cinema & 0.46 & $\begin{array}{l}0.0 \\
1\end{array}$ & $\begin{array}{l}0.9 \\
4\end{array}$ & 0.93 & 0.31 & $\begin{array}{l}0.9 \\
2\end{array}$ & $\begin{array}{l}1.0 \\
0\end{array}$ & $\begin{array}{l}0.0 \\
0\end{array}$ & -3.67 & $\begin{array}{l}\text { UnLikely } \\
\text { Manipulation }\end{array}$ & Profit \\
\hline $\begin{array}{l}\text { Zain MOBILE } \\
\text { TELECOMMUNICATION } \\
\text { S COMPANY }\end{array}$ & 1.23 & $\begin{array}{l}0.0 \\
0\end{array}$ & $\begin{array}{l}0.9 \\
5\end{array}$ & 1.26 & 1.29 & $\begin{array}{l}0.8 \\
9\end{array}$ & $\begin{array}{l}0.7 \\
3\end{array}$ & $\begin{array}{l}- \\
0.1 \\
5\end{array}$ & -3.37 & $\begin{array}{l}\text { UnLikely } \\
\text { Manipulation }\end{array}$ & Profit \\
\hline Kuwait Cement Company & 0.92 & $\begin{array}{l}0.0 \\
0\end{array}$ & $\begin{array}{l}1.0 \\
1\end{array}$ & 0.99 & 0.00 & $\begin{array}{l}1.0 \\
7\end{array}$ & $\begin{array}{l}0.3 \\
6\end{array}$ & $\begin{array}{l}0.0 \\
3\end{array}$ & -3.65 & $\begin{array}{l}\text { UnLikely } \\
\text { Manipulation }\end{array}$ & Profit \\
\hline The commercial real estate & 1.87 & $\begin{array}{l}0.0 \\
2\end{array}$ & $\begin{array}{l}1.0 \\
0\end{array}$ & 1.01 & 1.06 & $\begin{array}{l}0.1 \\
6\end{array}$ & $\begin{array}{l}0.4 \\
4\end{array}$ & $\begin{array}{l}- \\
0.0 \\
2\end{array}$ & -2.54 & $\begin{array}{l}\text { UnLikely } \\
\text { Manipulation }\end{array}$ & Profit \\
\hline $\begin{array}{l}\text { Future Kind \& } \\
\text { Entertainment \& Real Estate }\end{array}$ & 1.07 & $\begin{array}{l}0.0 \\
5\end{array}$ & $\begin{array}{l}1.0 \\
2\end{array}$ & 0.99 & 1.14 & $\begin{array}{l}0.9 \\
6\end{array}$ & $\begin{array}{l}0.0 \\
8\end{array}$ & $\begin{array}{l}0.1 \\
9\end{array}$ & -5.63 & $\begin{array}{l}\text { UnLikely } \\
\text { Manipulation }\end{array}$ & Profit \\
\hline $\begin{array}{l}\text { Al Midan Clinic for Oral } \\
\text { Health Services }\end{array}$ & 1.04 & $\begin{array}{l}0.0 \\
1\end{array}$ & $\begin{array}{l}1.1 \\
3\end{array}$ & 1.10 & 1.08 & $\begin{array}{l}0.9 \\
4\end{array}$ & $\begin{array}{l}0.3 \\
1\end{array}$ & $\begin{array}{l}0.1 \\
7\end{array}$ & -2.72 & $\begin{array}{l}\text { UnLikely } \\
\text { Manipulation }\end{array}$ & Profit \\
\hline
\end{tabular}




\begin{tabular}{|c|c|c|c|c|c|c|c|c|c|c|c|}
\hline $\begin{array}{l}\text { Agility Public Warehousing } \\
\text { Company }\end{array}$ & 1.11 & $\begin{array}{l}0.0 \\
0\end{array}$ & $\begin{array}{l}0.9 \\
9\end{array}$ & 1.10 & 0.97 & $\begin{array}{l}0.9 \\
1\end{array}$ & $\begin{array}{l}0.4 \\
5\end{array}$ & $\begin{array}{l}- \\
0.1 \\
5\end{array}$ & -3.90 & $\begin{array}{l}\text { UnLikely } \\
\text { Manipulation }\end{array}$ & Profit \\
\hline Ajwan Gulf Real Estate & 0.77 & $\begin{array}{l}0.7 \\
5\end{array}$ & $\begin{array}{l}0.9 \\
6\end{array}$ & $\begin{array}{l}1329.0 \\
0\end{array}$ & 0.00 & $\begin{array}{l}0.0 \\
0\end{array}$ & $\begin{array}{l}0.1 \\
2\end{array}$ & $\begin{array}{l}- \\
0.0 \\
8\end{array}$ & $\begin{array}{l}1178.9 \\
2\end{array}$ & $\begin{array}{l}\text { Likely } \\
\text { Manipulation }\end{array}$ & Profit \\
\hline National Industries Group & 1.12 & $\begin{array}{l}0.0 \\
0\end{array}$ & $\begin{array}{l}0.9 \\
8\end{array}$ & 1.13 & 0.91 & $\begin{array}{l}0.9 \\
6\end{array}$ & $\begin{array}{l}0.7 \\
1\end{array}$ & $\begin{array}{l}- \\
0.0 \\
3\end{array}$ & -3.07 & $\begin{array}{l}\text { UnLikely } \\
\text { Manipulation }\end{array}$ & Profit \\
\hline $\begin{array}{l}\text { Heavy Engineering } \\
\text { Industrise \& Ship Building } \\
\text { Co. }\end{array}$ & 0.97 & $\begin{array}{l}0.0 \\
0\end{array}$ & $\begin{array}{l}0.9 \\
7\end{array}$ & 1.07 & 0.96 & $\begin{array}{l}0.6 \\
0\end{array}$ & $\begin{array}{l}0.6 \\
9\end{array}$ & $\begin{array}{l}0.0 \\
0\end{array}$ & -3.07 & $\begin{array}{l}\text { UnLikely } \\
\text { Manipulation }\end{array}$ & Profit \\
\hline Kuwait Cable Vision & 1.00 & $\begin{array}{l}0.5 \\
0\end{array}$ & $\begin{array}{l}1.0 \\
0\end{array}$ & 0.67 & 0.00 & $\begin{array}{l}0.6 \\
7\end{array}$ & $\begin{array}{l}0.3 \\
1\end{array}$ & $\begin{array}{l}- \\
0.1 \\
2\end{array}$ & -4.40 & $\begin{array}{l}\text { UnLikely } \\
\text { Manipulation }\end{array}$ & Profit \\
\hline $\begin{array}{l}\text { Specialities Group Holding } \\
\text { Co. }\end{array}$ & 0.00 & $\begin{array}{l}0.0 \\
2\end{array}$ & $\begin{array}{l}1.0 \\
5\end{array}$ & 1.30 & 0.30 & $\begin{array}{l}0.3 \\
3\end{array}$ & $\begin{array}{l}0.2 \\
2\end{array}$ & $\begin{array}{l}0.4 \\
4\end{array}$ & -2.72 & $\begin{array}{l}\text { UnLikely } \\
\text { Manipulation }\end{array}$ & Profit \\
\hline Dar Al Thuraya Real Estate & 0.76 & $\begin{array}{l}0.2 \\
9\end{array}$ & $\begin{array}{l}1.0 \\
7\end{array}$ & 1.02 & 0.00 & $\begin{array}{l}0.8 \\
2\end{array}$ & $\begin{array}{l}0.3 \\
6\end{array}$ & $\begin{array}{l}- \\
0.0 \\
2\end{array}$ & -3.78 & $\begin{array}{l}\text { UnLikely } \\
\text { Manipulation }\end{array}$ & Profit \\
\hline $\begin{array}{l}\text { Gulf Cable \& Electrical } \\
\text { Industries Company }\end{array}$ & 1.00 & $\begin{array}{l}0.0 \\
0\end{array}$ & $\begin{array}{l}1.0 \\
0\end{array}$ & 1.36 & 0.92 & $\begin{array}{l}0.6 \\
8\end{array}$ & $\begin{array}{l}0.1 \\
4\end{array}$ & $\begin{array}{l}0.2 \\
2\end{array}$ & -3.62 & $\begin{array}{l}\text { UnLikely } \\
\text { Manipulation }\end{array}$ & Profit \\
\hline Shuaiba Industrial Co. & 1.03 & $\begin{array}{l}0.0 \\
1\end{array}$ & $\begin{array}{l}1.0 \\
0\end{array}$ & 0.93 & 0.57 & $\begin{array}{l}1.1 \\
0\end{array}$ & $\begin{array}{l}0.2 \\
1\end{array}$ & $\begin{array}{l}0.2 \\
6\end{array}$ & -3.06 & $\begin{array}{l}\text { UnLikely } \\
\text { Manipulation }\end{array}$ & Profit \\
\hline Jazeera Airways & 1.96 & $\begin{array}{l}0.0 \\
0\end{array}$ & $\begin{array}{l}0.5 \\
8\end{array}$ & 1.26 & 0.53 & $\begin{array}{l}0.9 \\
4\end{array}$ & $\begin{array}{l}0.7 \\
6\end{array}$ & $\begin{array}{l}0.0 \\
2\end{array}$ & -2.11 & $\begin{array}{l}\text { Possible } \\
\text { Manipulation }\end{array}$ & Profit \\
\hline Gulf Cement Company & 1.14 & $\begin{array}{l}0.0 \\
0\end{array}$ & $\begin{array}{l}1.0 \\
9\end{array}$ & 0.93 & 1.28 & $\begin{array}{l}1.0 \\
7\end{array}$ & $\begin{array}{l}0.2 \\
0\end{array}$ & $\begin{array}{l}0.0 \\
4\end{array}$ & -4.02 & $\begin{array}{l}\text { UnLikely } \\
\text { Manipulation }\end{array}$ & Profit \\
\hline Aan Digital Services & 0.81 & $\begin{array}{l}0.0 \\
1\end{array}$ & $\begin{array}{l}1.0 \\
0\end{array}$ & 1.55 & 1.33 & $\begin{array}{l}0.5 \\
5\end{array}$ & $\begin{array}{l}0.1 \\
7\end{array}$ & $\begin{array}{l}- \\
0.2 \\
2\end{array}$ & -5.20 & $\begin{array}{l}\text { UnLikely } \\
\text { Manipulation }\end{array}$ & Profit \\
\hline $\begin{array}{l}\text { Hayat Communications } \\
\text { Company }\end{array}$ & 0.00 & $\begin{array}{l}0.0 \\
1\end{array}$ & $\begin{array}{l}1.0 \\
1 \\
\end{array}$ & 1.06 & 1.07 & $\begin{array}{l}0.9 \\
2 \\
\end{array}$ & $\begin{array}{l}0.6 \\
2 \\
\end{array}$ & $\begin{array}{l}0.3 \\
4 \\
\end{array}$ & -2.47 & $\begin{array}{l}\text { UnLikely } \\
\text { Manipulation }\end{array}$ & Profit \\
\hline
\end{tabular}

\section{Analysis}

\subsection{Companies with "Likely \& Possible Profit Manipulation"}

\subsubsection{Company 1: Commercial Facilities Companies}

Altman Z-score = 1.99: Grey Area), Beneish M-score indicates likely profit manipulation (1.15>-1.78).

We did not find direct news on the bankruptcy of Commercial Facilities Company which showed a "likely profit manipulation". However, we noticed that there is latest news which was reported in (Skyline Gazette, 2020) regarding the growing revenues' concerns in the commercial facilities companies. After the rising demand on automation in this market, they urged commercial facilities' companies to enhance their revenue growth and profitability in order to gain the confidence of political parties. This increases the chances of their long term profitable contracts in the light of this markets' spur in growth. The results of Altman show that this company is in the grey zone which indicates a moderate potential of distress in the near future. Looking at the company's stock price, we noticed that the change in their stock prices is between $198 \$$ (as the lowest reported value) and $\$ 210$ as the highest value.

\subsubsection{Company 2: The National Real Estate Company}

Altman Z-score: Distress $(.78<2.67)$; Beneish M score result: possible profit manipulation (M score $=-2.22<-$ $2.11<-1.78)$

In a publication by Warrier (2019) in Construction Week online newspaper, they reported how NREC had a significant one time drop in their liabilities of $16.2 \%$ in the first six months of 2019 and loans and borrowings by 18.5\%. They added that when they spoke with Mr. Faisal Jamil Sultan Al-Essa, Chief Executive Officer, he said that they are implementing strategies to increase their cash position by decreasing debt level and enhancing their 
performance of operating properties and by developing landmark projects. However, they reported that they have reached an advanced level in their mega residential project (4km2 Grand Heights) in Egypt. He noted that this project has reached an advanced level of development. Beside all of these, we noticed in this news periodical that in May 2019, NREC was shortlisted along with other 6 real estate companies by the Municipality of Kuwait to submit their proposals for a coming great recreational project that will be implemented in Al-Egaila Area if Al Ahmadi Governate.

Based on the aforementioned factor, we logically suggest the following prototypes:

Likely profit manipulation would be for purposes to increase their chances to gain the bid that will be done for the Big project in Al-Egaila. It is possible that they manipulated their profits to increase their chances of being shortlisted among numerous number of real estate contracts who applied.

When it was noticed that the company's Egypt 4km2 Grand Heights project has reached an advanced level, it is estimated that their cost of debt has increase. In contrary, debt fell by $18.5 \%$ which is unusual. The company needs to provide further disclosures regarding what strategies they have implemented to ensure this instant and rapid growth and decline in debt rations.

The likelihood of these suggestions is high as the company reported a major increase of \$22 million in their net profits in the first quarter of 2019.

Although the likelihood of profit manipulation is high (-2.11), the expected revenues from upcoming projects are estimated to cause boost in their revenue growth and to decrease from the impact of possible manipulation on their going concern.

Beside the above factors, in the light of the latest burdensome that struck economies due to Covid-19, Al Khaleej Today Online Newspaper reported the following on March 28, 2020: "The rating actions stem from our view that, in 2020, the sharp drop in oil prices and reduced activity due to COVID-19 will exert significant pressure on the UAE economy, especially the real estate, trade, retail, transportation, and hospitality sectors," S\&P said in a note.

On the other hand, the results of Altman $Z$ score for this company showed that it is in distress area $(\mathrm{Z}=0.78<2.67)$ which means that this company is in a high chance to file for a bankruptcy. This is critical for the going concern of the NREC as being in the distress area affect investors' confidence in the company. This affects the long term profitability plans of the company that is highly dependent on successful Initial Public Offerings of their newly coming project, such as Grand height project which has reached an advances level.

\subsubsection{Company 3: Ajwan Gulf Real Estate}

Altman Z-score: Distress $(-1.05<2.67)$; Beneish M score result: possible profit manipulation $(\mathrm{M}$ score $=1178>$ 1.78)

There is high possibility of profit manipulation by this company due to sudden increase in their sales from $(0.001$ millions) in 2017 to 1.33 \$millions in 2018. All ratios that were used as inputs to calculate the M-score were in the required range except for the ratio of (Sales growth between previous year (2017) and current year (2018). Moreover, they have reported zero cost of sales in 2018 while they suddenly increased the cost of sales to 1.461 (in million values) in 2019. Due to the matching principle in Accounting Reporting Methods, costs have to be in a relative percentage of sales. It is unreasonable to have a value of zero for cost of sales in the year ended 2018 even though they had very low sales $(0.003 \mathrm{~m})$. These unusual changes in the financial statements highlighted the results of Beneish model that showed possibility of profit manipulation.

On the other hand, the results of Altman's Z-score showed that the company is in the distress zone which means that it was at a high risk to file for bankruptcy. Below is figure that is obtained from Morning Star (2020) that shows the deterioration in the company's stock profile as of September 2019:

\begin{tabular}{lll}
\hline Revenue 3 year growth: $56.39 \%$ & Operating Margin \%TTM: -56.97 & Free Cash Flow 2019: -33.56 \\
\hline Return on Assets \%TTM: -20.98 & Return on Equity \%TTM: $-23.12 \%$ & Net Margin \%TTM: -554.5 \\
\hline
\end{tabular}

Key Financial Rations of Ajwan Gulf Real Estate (Morningstar, 2020).

The latest stock profile and the listing of this stock in the international markets were released on February 5th, 2018 which verified how the distress result is true indicator of the poor investors' confidence in this company. The above figure shows how the key ratios have deteriorated significantly $(-34 \%$ decline in free cash flow, $-\% 554$ in net margin ratio, $-56 \%$ as a decline in the operating margin key ratio). 
Besides, we were not able to find the company's financial data as of 2019 which signals a possibility of its bankruptcy. The latest price for this company was KD10.5 which are considered very low. Referring to an article that was published by Reuters (2018), they reported the following: "Net loss attributable to shareholders 115,378 dinars versus loss of 98,949 dinars a year ago. Board proposes not to distribute dividend for year". Although the company has not formally filed for a bankruptcy, the results of Altman and Beneish models signals the high risk of going concern facing the company, the loss of investors' confidence in the company's financials, and lack of adequate publishing of the financial statements of the company each year end. Moreover, it would be because they are continuing the execution of the projects they have already initiated such as "industrial plots in Umm Al Quwain Industrial Land, United Arab Emirates, and residential plots in Khadra'a Al-Suwaiq, Oman".

\subsubsection{Company 4: Jazeera Airways}

Altman Z-score: Distress $(1.78<2.67)$; Beneish M score result: possible profit manipulation (M score $=-2.22<-$ $2.11<-1.78)$

Referring to the company's financials and news reported by Arabian Business Newspaper (2020), we noted the possibility of profit manipulation resulting from a sudden jump of its profits by $124 \%$ in 2019 due to a surge in passenger numbers. The company has made the required disclosures that proved the reasons of this one sudden increase. There was evidence of an increase in number of passengers by $20.6 \%$ where they reached 2.4 million, and an increase of $25.9 \%$ in their operating revenue to reach KD 103.7 million. Moreover, they have registered an increase of $108.7 \%$ in operating profit due to the increase of $77.5 \%$ in load factor.

However, the results of Z-score in distress zone and the M-score that reflected possible profit manipulation was due to the reported net loss of KD 1.8 million by the fourth quarter of 2018. The company was failing financially as of 2018, the company invested heavily in a cost focus approach that allowed its recovery. This means that Altman and Beneish Model successfully highlighted the financial downturn and high likelihood to file bankruptcy if they continued facing net losses. However, Mr. Marwan Boodai, reported the following to Arabic Business Newspaper: "We are proud to be announcing our best set of operating results in the airline's history. The significant leap in profitability is the result of profitable growth coupled with an aggressive cost focus." He added: "Our airline continues to grow and expand its footprint in the Middle East, Europe and Asia, while our Jazeera Terminal $\mathrm{T} 5$, which is the only example of an airline-owned terminal in the region, significantly contributed to the strong results". This shows how Jazeera Airways admitted their financial failure in the years 2017-108 which was validated in the result of Altman's and Beneish Model, but they successfully ensured their recovery due to several strategies related to cost focus and their airline owned terminal T5 that is leading to their enhanced stronger performance.

\section{Conclusion}

The Altman model highlighted 22 companies out of the chosen 30 are in financial distress. This means that Altman highlighted financial failure in $73 \%$ of the sampled companies which is considered significantly high. To find meaningful explanation of the high cases that indicated potential failure. By examining the companies in distress we noticed that these companies are of the following types: the majorities are real estate and manufacturing companies. This was explained by the initial Altman (1968) paper which provided possible explanations for the following companies: (1) Real estate and manufacturing companies have large inventory records on their statements, and they record high sale, but report lower profit margins. In a manufacturing company, the size \& timing of the inventory along with that of the accounts receivable plays a big role in impacting safety and ratio analysis. If the company is facing any issues with its liquidity and in its working capital in specific, then this would provide a valuable input to the effectiveness of the Altman's test. Moreover, this ratio was modified to represent each type of firm properly. For example, in manufacturing, working capital represents inventory and its potential cash liquidity of inventory. These companies may report a distress in Altman's test at times, but then the results of the test would change upon collection of receivables and sale of inventory. Therefore, we focused our discussion section on companies that indicated possible profit manipulation. This is because the initial aim of Beneish model was to complement Altman's formula. The results of Altman would be very detrimental in protecting external stakeholders, mainly, creditors, bankers, and shareholders. It signals high possibility of likelihood to settle debt on time due to financial stress issues they encounter either due to low working capital, liquidity issues, late collection of receivables, although they may report high sales ratios. We focused on the results of Beneish as it is a strong predictor of manipulation in a more detailed way than the Altman model. The success of these models has been assured by similar scholars who tested these models on individual companies and larger stock markets. To examine the effectiveness of companies that showed profit manipulation, we investigated the company and the related new about it. We were successfully able to approve the effectiveness of these models in reflecting possibility of profit 
manipulation. We found that the public has acknowledged the financial difficulties the four companies of Jazeera Airways, Ajwan Gulf Real Estate, The National Real Estate Company, and Commercial Facilities Companies that revealed "possible profit manipulation". We were able to substantiate the potential underlying causes distress. When we tested the accuracy and strength of this model, we were able to verify jump in sales prior to the opening of the governmental bids for huge projects. Therefore, by linking two piece of information, we were able to verify that there was a reason why this company manipulated its profits and financial indicators.

In conclusion, Beneish and Altman proved to have high predictive power in the context of Kuwait Stock Exchange listed companies. Altman's reported distress was not valid for all types of companies due to certain exceptions that were found. The less predictive power was due to reasons related to inventory cycles in companies of real estate and manufacturing companies. However, we cannot deny the high predictive power to reflect the actual working capital deficiencies and in other indicators of financial distress. Although there was relevant justification for these reasons, Altman as a model highlighted in an accurate way these deficiencies. Therefore, the predictive power of Altman in industrial and real estate companies is low like what was found in other research. This does suggest the common feature in developing countries regarding the length of collection cycles and high inventory levels. These two issues could be addressed by a recalibration of the intervals to account for industry/country specific idiosyncrasies. Moreover, our findings allow us to reach the conclusion that Beneish is an effective tool for financial analysts and external auditors for early detection of profit manipulation. Other major conclusion is Beneish has a high predictive power as it is retroactive in its calculation. In includes comparisons between current and past year unlike Altman that focuses on one-year ratio analysis only. This increases its effectiveness against Altman model. Therefore, we stand by the recommendation that for higher accuracy both models should be interrelated and included jointly in analysis.

\section{References}

Alareeni, B., \& Branson, J. (2013). Predicting Listed Companies' Failure in Jordan Using Altman Models: A Case Study. International Journal off Business and Management, 8(1), 113-126.

Altman, E. I. (1968). Financial ratios, discriminant analysis and the prediction of corporate bankruptcy. Journal of Finance, 23, 589-610.

Altman, E. I., \& Lavalle, M. (1981). Journal of Business Aministration, 12, 147-164.

Aris, N. A., Arif, S. M., \& Zain, M. M. (2015). Fraudulent Financial Statement Detection Using Statistical Techniques: The Case Of Small Medium Automotive Enterprise. The Journal of Applied Business Research, 31(4), 1469-1478.

Association of Certified Fraud Examiners. (2008). Report to the Nation on Occupational Fraud and Abuse. Retrieved from SMC Blackboard Learning Resource

Beneish, M. D. (1999). A Note on Wiedman's (1999) Instructional Case: Detecting Earnings Manipulation. Issues in Accounting Education, 14(2), 369-370.

Bhavani, G., \& Tabi, C. (2017). M-Score and Z-Score for detection of Accounting Fraud. Accountancy Business and the Public Interest, 68-86.

Deloitte. (2008, December 29). Ten Things about Financial Statement Fraud (2nd ed.). Retrieved from http://www.deloitte.comdtt/cda/doc/content/

Golec, A. (2019). Effectiveness of the Beneish Model in Detecting Financial Statement Manipulations. Retrieved from https://czasopisma.uni.lodz.pl/foe/article/view/3090

KPMG. (2015). Fraud Risk Management: Developing a Strategy for Prevention, Detection and Response. Retrieved from http://www.us.kpmg.com

Harrington, C. (2005). Formulas for Detection: Analytical Ratios for Detecting Financial Statement Fraud. Association of Certified Fraud Examiners. Fraud Magazine.

MacCarthy, J. (2017, November). Using Altman Z-score and Beneish M-score Models toDetect Financial Fraud and Corporate FailuA Case Study of Enron Corporation. Retrieved from Researchgate: https://www.researchgate.net/publication/321143663

Mavengere, K. (2015). Predicting Coprorate Bankruptcy and Earnings Manipulation Using the Altman Z-score and Beneish M-score. The Case of Z Manufacturing Firm in Zimbabwe. International Journal of Management Sciences and Business Research, 4(10), 8-14.

Newstex Global Business. (2016). ValueWalk: How to detect earnings manipulation. Chatham: Webblog Post. 
Oeconomia Copernicana. (2017). Comparison of liquidity based and financial performance based indicators in financial analysis. Torun, 8(1), 83-97.

Pustylnick, I. (2009, January 4). Combined Algorithm of Detection of Manipulation in Financial Statements. Retrieved from http://www.ssrn.com/abstract=1422693

Robinson, R. A., \& Magure, M. G. (2001). Top Common Causes of Construction Contractor Failures. Journal of Construction Accounting \& Taxation.

Roshayani, A., Sharinah, M., \& Normah, O. (2015). Prediction of Business Failure and Fraudulent Financial Reporting: Evidence from Malaysia. Indian Journal of Corporate Governance, 8(1), 34-53.

\section{Copyrights}

Copyright for this article is retained by the author(s), with first publication rights granted to the journal.

This is an open-access article distributed under the terms and conditions of the Creative Commons Attribution license (http://creativecommons.org/licenses/by/4.0/). 